\title{
Copiar o crear. La postmodernidad desde el cine de Michelangelo Antonioni y Brian de Palma
}

\section{Copy or Creation. Postmodernity from films by Michelangelo Antonioni and Brian de Palma}

\author{
Inmaculada Murcia Serrano \\ Universidad de Sevilla. \\ Departamento de Estética e Historia de la Filosofía. Sevilla, España \\ imurcia@us.es
}

Resumen : Utilizando dos películas como pretexto, Blow up de Michelangelo Antonioni y Blow-out de Brian de Palma, en este artículo se abordan distintas teorías postmodernas en relación al impacto de las nuevas tecnologías sobre la distinción metafísica y moderna entre esencia y apariencia. A la luz de los dos films, se estudian y valoran los conceptos de «simulación» y «simulacro", así como los presupuestos del pensamiento débil en relación a la desaparición tecnológica de la realidad.

Palabras clave: postmodernidad, nuevas tecnologías, apariencia, realidad, simulacro.

Abstract • Using two movies as an excuse, Blow up by Michelangelo Antonioni and Blow-out by Brian de Palm, this article will approach different postmodern theories according to the impact of new technologies on the metaphysical and modern distinction between essence and appearance. In the light of both films, the concepts of «simulation» and «simulacra» will be studied, as well as the budgets of «weak thought» in relation to the technological disappearance of reality.

Keywords: postmodernity, new technologies, appearance, reality, simulacra.

En su conocido ensayo La lógica cultural del capitalismo tardío (1984), Frederic Jameson nos invita a comparar, en una insignificante anotación, dos películas: Blow-up (1966) de Michelangelo Antonioni y el discutible remake que de ella hizo años después Brian de Palma con el título Blow-out (1981) (traducido en España como Impacto). ${ }^{1}$ Nos invita a hacerlo para ilustrar una alteración semántica y postmoderna de la categoría estética de

1 Digo «discutible» porque el propio Brian de Palma reconoció que la recepción de su película «fue una gran decepción» (Cantero, 2000). Véase también la crítica que le hace Enrique Colmena (1987). 
lo sublime en su versión descafeinada: considera Jameson que una parte de la producción artística postmoderna, la más débil, se ha hecho eco de la expansión ilimitada de las nuevas tecnologías de reproducción tratándolas tan sólo como "tema» de sus producciones cinematográficas o literarias, diluyendo así el poder atemorizante a la vez que delicioso - propio de lo sublime - que en realidad provocan y que la corriente literaria del ciberpunk sí habría conseguido estimular (Jameson, 1997: 57). ${ }^{2}$ Como ejemplo de esa versión torpe de lo «sublime postmoderno o tecnológico», Jameson menciona la película de Brian de Palma, en la que todo un despliegue de artefactos reproductivos se confabula con una trama de conspiraciones y asesinatos que remite, sin lugar a dudas, a la mítica película de Antonioni, en la que, contrariamente, sólo una de esas máquinas, la cámara fotográfica, se basta para hacernos pensar (57).

Esta comparación posee, sin embargo, virtualidades mucho más sugestivas que las que Jameson parece apreciar. Desde su propio ensayo y de la mano de otros teóricos más o menos afines se puede levantar toda una diferenciación en términos de moderno/postmoderno en relación con estas dos conocidas cintas. Puesto que se trata de una reflexión estrictamente filosófica y/o estética, nos concentraremos en los aspectos argumentales de las películas, dejando a un lado el propio lenguaje cinematográfico cuyo análisis sobrepasaría con creces, sobre todo en el caso de Antonioni, la extensión y la finalidad de este artículo de investigación.

\section{BLOW-OUT O EL ARTE DE COPIAR LA REALIDAD}

Se podría estar tentado a pensar que el hecho de que Blow-up sea quince años anterior a Blow-out y que la de este último pueda considerarse a su vez un remake, que la hace ser más postmoderna. No faltan razones para pensarlo. El propio Frederic Jameson ha identificado como uno de los rasgos característicos de la postmodernidad la ausencia de estilo, entendiendo por ello la huella subjetiva que identifica al autor. En sustitución, habría aparecido la estética del "pastiche» - término que extrae del Dr. Faustus de Thomas Mann- en la que podemos ubicar muchos remakes cinematográficos, y que, al contrario de lo que ocurriera con el estilo, vendría a hacer desaparecer la individualidad en aras de una "canibalización» aleatoria y puramente estética de los elementos formales y de contenido del pasado. La estética del pastiche, como imitación de un estilo peculiar o único y como "parodia vacía», al tiempo que convierte la obra en un «texto» huero, hinchado gracias a la «inter-textualidad», traería como consecuencia la transformación

\footnotetext{
Según Jameson, el poder que ostentaba tradicionalmente la naturaleza para atraer y repeler al sujeto y que condujo a Edmund Burke o a Immanuel Kant a desarrollar sus respectivas aproximaciones a la categoría estética de lo sublime ha desaparecido en la postmodernidad. No así la categoría referida que, en opinión de este autor, habría adquirido un nuevo significado relacionado, no ya con la naturaleza, sino con la inmensa red comunicativa e informática en la que nos movemos en la actualidad. Esta red, de fuerte poder hipnótico y fascinante — sublime-, constituiría, a su vez, no más que una «imagen distorsionada» de algo mucho más profundo: el sistema mundial del capitalismo multinacional. Para Jameson, lo que se denomina ya "sublime tecnológico" se encontraría, pues, en todas esas narrativas postmodernas de evasión que profundizan en la llamada «paranoia high-tech» y en la que se despliegan los circuitos y las redes de una supuesta alianza informática universal, que activa conspiraciones laberínticas de agencias rivales de espionaje con una complejidad que rebasa la mente del lector. De ellas habría nacido la corriente ciberpunk, que vendría a ser la expresión más cabal de esas realidades empresariales transnacionales y de la propia paranoia global (1996: 57).
} 
de la historia en un conjunto desfondado de imágenes y de textos. Para Jameson, todavía en la estela marxista y siguiendo de cerca al situacionista Guy Debord, ello tendría que ver con el apetito social por consumir un mundo transformado en imágenes, las cuales se habrían alzado ahora como la nueva forma de reificación de la mercancía.

Dejando al margen la perspectiva ideológica con la que Jameson hace frente al pastiche, hemos de decir que, efectivamente, esta es una de las evoluciones que se aprecia entre la cinta de Michelangelo Antonioni y la de Brian de Palma. Tanto es así que el director norteamericano no ha podido escapar a la recurrente acusación, divulgada por numerosos críticos, de haber tomado prestado o incluso plagiado a otros directores, especialmente a Alfred Hitchcock. ${ }^{3}$ Por eso, no es extraño encontrar en Blow-out numerosos guiños a películas anteriores, en este caso, a Blow-up. Por ejemplo, la escena en la que Thomas amplía las fotografías de la pareja de amantes tomadas en el parque para reconstruir lo que ocurrió — escena, por cierto, "canibalizada» en otras películas de culto $^{4}$ - reaparece metamorfoseada en Blow-out (debido a los avances técnicos que han aparecido en el intervalo de tiempo que media entre una y otra) cuando Jack hace de las imágenes del supuesto accidente del gobernador publicadas por la prensa una película a la que agrega el sonido grabado por él in situ, reconstruyendo así, como el protagonista de Antonioni, el acontecimiento del que fue testigo sonoro y visual. La trama del film también está tomada, aunque de forma un tanto melindrosa y destruyendo su ambigüedad, de la película de Antonioni. Igualmente se hacen diversas relecturas, más o menos camufladas en el guión, de cuestiones que se plantean en la película de Antonioni, como la transformación que la tecnología opera sobre la realidad, la reflexión sobre la ficción cinematográfica, el paralelismo entre Sally, maquilladora de profesión, y los cómicos de Blow-up, etc.

Antonioni no es, sin embargo, el único director al que De Palma envía guiños. Como era de esperar y más allá del referente remoto que constituye La ventana indiscreta - con la que se puede relacionar la inclinación de los personajes depalmianos hacia el vouyerismo (una inclinación que también ha sido detectada en el cine de Antonioni ${ }^{5}$ )-, Hitchcock es agasajado también, no sin cierta ironía típicamente postmoderna, justo al comienzo de la película, cuando se recrea la famosa escena de la ducha de Psicosis, que es tratada además como lo que es, una «escena cinematográfica» — pura imagen- digna de ser rememorada, pero a la que le falta el grito insustituible de Janet Leigh. Por último podemos subrayar que el tema de la escucha, que medula todo el guión, tiene como precedente La conversación de Francis Ford Coppola.

Brian de Palma siempre ha contestado igual a dicha imputación: «Simplemente trato de utilizar cosas que hayan funcionado antes con la idea de que vuelvan a funcionar» (En Cantero: 60). Para el tema de la recepción crítica de los guiños depalmianos al cine anterior, véase también, del mismo libro, pp. 93-99 y pp. 104-107.

4 Véase por ejemplo la maleabilidad que adquiere la imagen fotográfica de una de las replicantes en la escena de Blade Runner (Ridley Scott, 1982) en la que Harrison Ford busca en ella pistas para su investigación.

5 Para un estudio sobre el juego de las miradas en el cine de Antonioni, véase Bou, Nuria (2002). Para el caso de Brian de Palma, véase Colmena (1987). 


\section{Desde el pensamiento débil: el «reventón» tecnológico de lo real}

Pero hay algo más que podría conducirnos a pensar que la película de Brian de Palma es más postmoderna que la de Antonioni. Tengamos en cuenta que una de las afirmaciones más extendidas entre los pensadores de la postmodernidad tiene que ver justamente con la idea de que la realidad, que antaño ofrecía «resistencia», se está descomponiendo en imágenes en virtud de la transformación que sobre ella imprimen las nuevas tecnologías, especialmente las utilizadas por los medios de comunicación. Esta afirmación constituye uno de los cimientos del llamado «pensamiento débil», que, apropiándose de la consideración heideggeriana del ser como "evento» (Ereignis) y aferrándose a la frase de «identidad» y «diferencia» en la que Heidegger declara que el Ge-stell («imposición» técnica) constituye "un primer centelleo del Ereignis», considera a la realidad como algo fluido (en Vattimo, 1998). Gianni Vattimo, su principal promotor, opina que esa frase de Heidegger, más que convertir a la técnica en la culminación de la metafísica en tanto forjaría el mundo manteniendo la contundencia de lo real, del ontos on de Platón, lo que hace es establecer su superación, al «debilitar», precisamente, su fortaleza. Por eso defiende que en la sociedad postmoderna de los media se habría llevado a cabo la famosa "profecía» de Nietzsche, prácticamente el lema bajo el cual se auspicia el pensamiento débil: que el mundo real se convierte en fábula (El crepúsculo de los ídolos). Para Vattimo, que reanuda así las consideraciones de Nietzsche y de Heidegger, la idea de la realidad que podemos tener en la modernidad tardía ya no se corresponde con el dato objetivo que está por debajo o más allá de las imágenes que de ella nos ofrecen los medios. Contrariamente, éstos, que intensifican las posibilidades de información, hacen paradójicamente menos concebible la idea misma de "una» realidad. Naturalmente, ello trae consigo transformaciones importantes en la noción de realidad: «La realidad, para nosotros, es más bien el resultado de cruzarse y <contaminarse〉 (en el sentido latino) las múltiples imágenes, interpretaciones, reconstrucciones que distribuyen los medios de comunicación en competencia mutua y, desde luego, sin coordinación «central〉 alguna» (Vattimo, 1994: 15). La realidad, por decirlo de otra manera, se correspondería ahora con el «relato» mediático (el cuento, la fábula) más o menos consensuado (microrrelato) de los acontecimientos, que, lógicamente, coloca en serios apuros a los grandes relatos de emancipación (Grands récits), que requieren un fundamento fuerte y de los que Jean-François Lyotard había ya vaticinado su disolución (1994). Por su parte, Vattimo no opina que la sociedad de la comunicación sea por ello más transparente, sino, todo lo contrario, mucho más caótica y compleja, pero cree en paralelo que en esa complejidad de microrrelatos des-fondados residen justamente nuestra oportunidad (chance) de habitar el nihilismo y nuestras esperanzas de emancipación, que distan de parecerse a las encumbradas por el pensamiento ilustrado. ${ }^{6}$

Para Vattimo, la multiplicación tecnológica y massmediática de las imágenes del mundo por la cual perdemos el «sentido de la realidad» no es, pues, una grave pérdida puesto que ello posibilita - aunque con prevenciones - la liberación de las diferencias, de las «racionalidades locales». Vivir en este mundo múltiple significa experimentar la libertad

«En la sociedad de los medios de comunicación, en lugar de un ideal de emancipación modelado sobre el despliegue total de la autoconciencia, sobre la conciencia perfecta de quien sabe cómo están las cosas (bien sea el Espíritu Absoluto de Hegel o el hombre liberado de la ideología como lo concibe Marx), se abre camino un ideal de emancipación que tiene en su propia base, más bien, la oscilación, la pluralidad, y, en definitiva, la erosión del mismo 〈principio de realidad»» (Vattimo, 1994: 15). 
como oscilación continua entre la pertenencia y el extrañamiento. Vattimo reconoce que se trata de una libertad problemática, no sólo porque tal efecto no está garantizado (los media, dice, pueden convertirse también en la voz del Gran Hermano o de la banalidad estereotipada), sino porque, además, desconocemos qué fisonomía tienen y porque nos fatiga concebir esa oscilación como libertad: la nostalgia de los horizontes cerrados - reconoce el filósofo- sigue aún fuertemente edificada en nosotros. Lo saludemos o no con entusiasmo, mantengamos mayores o menores reservas ante la imparable estetización mediática de la realidad, lo que parece claro es que, desde este punto de vista, la realidad ya no coincide con lo estable, lo fijo y lo permanente, sino que tiene más que ver con el acontecimiento, el consenso, el diálogo o la interpretación.

El argumento de las dos películas que nos ocupan gira, desde luego, en torno a la mediación que la técnica introduce entre apariencia y realidad, aunque con la diferencia de que una lo plantea alrededor de la cámara fotográfica, una máquina de extremada sencillez, mientras que la otra, como indica Jameson, lo hace desplegando una tecnología reproductiva mucho más sofisticada, el vídeo, en la que se incluye tanto lo audio como lo visual. Si lo que sostiene el pensamiento débil es cierto y si la película de Brian de Palma puede considerarse un film postmoderno, como sugiere Jameson, entonces tal vez deberíamos concluir que el exorbitante despliegue tecnológico de Blow-out, característico de la filmografía depalmiana, ${ }^{7}$ debería desestabilizar, mucho más que la simple cámara fotográfica de Antonioni, la permanencia, fortaleza y solidez de lo real. Ello podría incluso explicar el significado de los títulos que estos dos realizadores confirieron a sus películas: si la cámara fotográfica es demasiado «débil» para "debilitar» la realidad, blow up, que significa «ampliar» pero también «sacar a la luz», es un buen verbo para expresar que la técnica fotográfica todavía «revela», nunca mejor dicho, lo verdadero, dejando intacta su consistencia; de la misma manera, si el vídeo es un aparato mucho más potente para languidecer la realidad, entonces el verbo blow out, que aparte de "pinchazo" significa «desvanecerse», resulta también idóneo para destacar el «impacto» que las nuevas tecnologías operan sobre la realidad, que, como el neumático de la película, se «desinfla» irremediablemente. Pero, ¿es esto lo que nos muestra la película de De Palma?

Blow-out ofrece sin duda alguna un claro testimonio de lo que la técnica es capaz de hacer con la realidad; por extensión, plantea el controvertido tema de la relación entre lo aparente y lo verdadero. No ha de extrañar, por eso, que encontremos en ella una gran cantidad de mentiras y de verdades, de juegos y malabarismos entre lo ficticio y lo real, que se entretejen además de manera laberíntica. Por ejemplo, el director norteamericano juega a despistarnos, simbolizando lo que va a ocurrir, en la primera escena de la película, en la que, sin más información, vemos un internado femenino a punto de ser atacado por un maníaco sexual. El director nos oculta que, en realidad, la escena a la que estamos asistiendo como espectadores es ella misma ficticia, pues forma parte de la película que el protagonista de Blow-out está produciendo en su estudio. Por eso, como ha indicado Marcial Cantero, en el momento en el que el público descubre la verdad, desaparece el suspense, pero a cambio se nos alumbra, como si de una moraleja se tratase, el problema sobre el que, en el fondo, se pretende reflexionar, a saber, "que la representación de la realidad no siempre es fiable» (2000: 60). Sin embargo, voy a intentar demostrar que, en lo que respecta a la relación entre lo aparente y lo real y sobre todo a la mediación que

Para la importancia de la técnica en el cine de Brian De Palma y las opiniones de éste acerca de la tecnología, véase Colmena (1987). 
entre ellos introduce la tecnología, este comienzo es más osado que el resto la película, pues en ella se nos adiestra efectivamente sobre lo poco fiable que es la representación de la realidad, pero nunca se pone en cuestión, como sí lo hace la presentación al comienzo de la escena del internado y la propia película de Antonioni, que lo ficticio pueda llegar a hacerse, en el sentido nietzscheano, verdadero. Existen enormes diferencias entre una y otra cuestión.

Habría que recordar algunas otras señales que De Palma deja caer en la película para prevenirnos de los engaños de las apariencias, como, por ejemplo, los comentarios que hace Sally, maquilladora de profesión, acerca de cómo disimular los defectos del rostro con un buen maquillaje - premonición de lo que van a efectuar los medios de comunicación como «cosméticos» de lo real (Lipovetsky, 1990)—, o también cuando, al final de la película, Jack incorpora el grito que Sally profiere en el momento de su asesinato y que, como él dice, "es un buen grito» porque sencillamente - y dramáticamente- es «real», a la escena "ficticia» de la ducha del internado, a la que, al principio de la película, le falta — macabra coincidencia- «veracidad». Destaquemos las diferencias que De Palma - desconozco si consciente o inconscientemente- establece entre esta escena y la del juego de tenis de los mimos de Blow-up: mientras que el grito de la chica asesinada hace que la película que Jack está rodando "parezca más verdadera», la participación de Thomas en el partido imaginario de tenis hace, contrariamente, que el juego mismo «se convierta en real», como lo demuestra el que, a partir de su colaboración, comience a escucharse el rebote de la pelota. De nuevo, como ocurre en la escena inicial del internado, la diferencia es abismal: una cosa es que algo parezca real y otra que lo termine siendo. Volveremos sobre ello.

Analicemos ahora el papel que ejerce la tecnología en estos juegos entre apariencia y realidad. La película Blow-out se desarrolla, como ya hemos mencionado, en el seno mismo de la ficción cinematográfica, pues el protagonista se dedica profesionalmente a producir películas de serie B. Coherente con ello, dentro de la película se pueden encontrar varias "películas», entendiendo el término tanto en su sentido literal como en el peyorativo y popular que lo empareja con la mentira: en primer lugar, y dejando aparte la que está ambientada en el internado femenino y que Jack y su equipo ultiman, podemos mencionar la «película» que los conspiradores inventan para hacer pasar el asesinato del gobernador por un accidente. En este caso, los confabulados no manipulan tecnológicamente los datos, pero sí hacen uso de los medios de divulgación de masas, aquellos que, en palabras de Vattimo, distribuyen su interpretación de la realidad, sólo que dicha interpretación está basada en testigos que mienten u ocultan los datos (es lo que hace el periodista que publica la secuencia fotográfica del accidente y que afirma en televisión que no hubo ningún asesinato). Efectivamente la realidad se convierte en fábula, pero en el peor sentido de la palabra. Para mostrar una verdad falsa, los conspiradores también alteran las pruebas manualmente (como cuando Burke cambia en el garaje la rueda disparada por una pinchada).

En segundo lugar, encontramos la «película» que Jack reconstruye, ahora sí, tecnológicamente, al agregar el sonido grabado in situ a las fotografías secuenciadas del accidente que se publican en un medio de comunicación, escena, por cierto, que da pie a la reflexión de Frederic Jameson acerca de la sofisticación tecnológica que exhibe esta película en comparación con la sencillez de la que hace gala Blow-up. Con respecto a lo que afirma Gianni Vattimo, nos encontramos aquí con otra contradicción: si asumiéramos los presupuestos del pensamiento débil para interpretar esta película desde coorde- 
nadas postmodernas, nos veríamos abocados a decir que la reconstrucción tecnológica del asesinato, en tanto estetización mediática de lo real, desvanece el dato objetivo exterior, convirtiendo lo real en fábula y sustituyendo la evidencia de «una realidad» por la relatividad de las «interpretaciones múltiples». Sin embargo, lo que ocurre en la película parece ser justo lo contrario: la reproducción técnica del asesinato en absoluto desnaturaliza lo real, puesto que no deja de ser una copia perfecta del dato objetivo exterior, lo que quiere decir que mantiene intacta la diferencia entre lo aparente y lo real; y no sólo eso: la reconstrucción tampoco nos obliga a reemplazar la idea de «una» realidad por la de «diversas» interpretaciones, puesto que lo que permite la tecnología utilizada por Jack es, precisamente, estabilizar el referente, la realidad, hasta el punto de que la película que filma se convierte en la única prueba de la Verdad —escribámosla con mayúsculas-, que puede demostrar la confabulación política que se esconde tras la muerte del gobernador, razón por la cual todos los interesados quieren apoderarse de ella. Quiere ello decir que la técnica, como el propio De Palma opina, tal vez sea neutral, y que el verdadero responsable de la tergiversación y de la "pérdida del principio de realidad", de nuevo en su peor sentido, es siempre el ser humano.

Lo que nos interesa resaltar es que la tecnología, al menos en este ejemplo, lejos de desinflar la realidad, como sostiene el pensamiento débil, parece más bien que la fortifica. Y lo hace porque De Palma, que en otros asuntos es tan postmoderno, en ningún momento pone en cuestión la existencia misma de lo real, esté o no mediado tecnológicamente. Desde que Jack demuestra que el sonido registrado en su grabadora en el escenario del crimen se corresponde con una detonación, los espectadores de Blow-out conocemos, sin lugar a dudas, que lo que en verdad ha ocurrido es un asesinato. De igual modo, sabemos que la prueba audiovisual que el protagonista reconstruye reproduce momento a momento y plano a plano el acontecimiento, mientras que la información que suministran los medios, confabulados con los conspiradores, está desde su origen contaminada. Conociendo la filmografía depalmiana, no es de extrañar que lleguemos a esta conclusión, pues buena parte de su producción cinematográfica, bastante pesimista en este sentido, gira en torno al tema de las conspiraciones políticas (véase Greetings, acerca del asesinato de Kennedy) y a la batalla contra el sistema dominante o establishment, que a su parecer y debido a la manipulación a que somete los datos, está perdida de antemano. ${ }^{8}$ También es propio de la visión depalmiana del mundo considerar que existe un hiato insalvable entre la realidad y su representación mediática, que nunca es objetiva, aunque como ha dejado claro en algunas entrevistas, el realizador cree firmemente que no todo es relativo, que existen diferencias entre el bien y el mal y que es posible distinguir, aunque los medios se empeñen en poner cada vez más obstáculos, lo aparente de lo real. ${ }^{9}$

En este sentido, se puede decir que Jack es un trasunto de Brian de Palma, pues, a lo largo de la película y pese a poner en peligro su propia vida, le escuchamos defender que existe «una única verdad», y que ésta debe hacerse pública si lo que queremos es preservarnos íntegros. El tono pesimista de la película no desarticula la existencia inexpugnable del acontecimiento. Y por mucho que el Poder consensúe que lo que ha ocurrido ha sido un accidente, el acuerdo, por interesado, no sólo no nos hace libres, como sugiere

\footnotetext{
Véase Colmena (1987), capítulos titulados «El poder, el poder» y «Kennedy, Oswald, Warren».

«Creo que hoy día ya no existen las informaciones objetivas. No existen verdades. Todo es relativo. Sin embargo, creo que tiene que haber una única verdad. Creo que existe una diferencia entre el bien y el mal. Pero eso no lo vemos en los medios». Entrevista con Rocío Ayuso, El Espectador, nº 7, p. 13, 1999 (en Cantero, 2000).
} 
Vattimo, sino que, al menos en esta película, es incapaz de reemplazar lo real, porque la película nos muestra sin ambages que lo real —el asesinato- sí ha tenido lugar. Conviene recordar esta fuerte aseveración realista para contraponerla a lo que ocurre en la película de Antonioni. Que lo real sea manipulado por el Poder, que los datos se falsifiquen, que los testigos mientan o que la única prueba de lo que ocurrió desaparezca puede que proporcione una visión pesimista del mundo en que vivimos (lo que desautorizaría también el tono entusiasta con el que Vattimo, aun con prevenciones, da la bienvenida a la sociedad postmoderna), pero desde luego deja incólumes las cuestiones relativas al estatuto mismo de lo real. No defiendo que De Palma las deje ilesas porque se considere un metafísico: tal vez su postura tenga más relación con el hecho de que la idea de verdad suele aparecer vinculada, para lo bueno y para lo malo, a la retórica del poder, ${ }^{10}$ tan recurrente en su filmografía. Provenga de donde provenga, el discurso ideológico que sostiene Blow-out se relaciona, en definitiva, con una visión racionalista del mundo, "discursiva» en términos de Lyotard, ${ }^{11}$ en la que se siguen manteniendo las dicotomías entre verdadero y falso y entre el bien y el mal porque, en el fondo, se confía aún en la existencia misma de un fundamento que da consistencia al «principio de realidad». Desde tales caracteres resultaría, por tanto, bastante difícil etiquetar Blow-out como una película postmoderna.

\section{Desde Jean Baudrillard: un video más real que lo real}

Pero volvamos a la reconstrucción tecnológica del asesinato que Jack lleva a cabo en su estudio. Como acabamos de comprobar, la sofisticada tecnología que el protagonista utiliza no fluidifica lo real, sino que se podría decir que lo "condensa»: consigue que al menos los espectadores y los protagonistas de Blow-out obtengamos un certificado del suceso cristalizado gracias a la tecnología, una confirmación indubitable y transparente de lo que realmente ocurrió. La magia que la tecnología audio-visual opera sobre el acontecimiento no es pues la manipulación que miente y falsea o que, llevado al extremo postmoderno, «derrite» el suceso como un helado bajo el sol, pues nada de lo que ocurrió en el escenario del crimen es desnaturalizado por ella; por contra, se podría decir que la magia que sobre lo real se maniobra tiene que ver, precisamente, con su cumplimiento, con su «real-ización», con su reconstrucción cabal y verdadera, completa y sin fisuras, exenta de ambigüedades, incertidumbres o sospechas. De ahí la importancia de guardar en un lugar seguro la cinta reconstruida del asesinato y de ahí también el interés de los conspiradores por hacerse con ella a toda costa (asesinato de Sally incluido).

Ahora bien, podríamos estar tentados a pensar que estas características se corresponden con lo que otros teóricos postmodernos, como Jean Baudrillard, denominan «hiperrealidad», y que, en consecuencia, la película que nos ocupa entraría dentro de la denominación de postmoderna aunque en un sentido distinto — de hecho contrapuesto— al que sustenta al pensamiento débil. Vamos a comprobar si puede ser entendida así.

10 La disputa entre la veracidad o falsedad de ciertas creencias, dice Zigmunt Barman, es siempre simultáneamente la discusión sobre el derecho de algunos a «hablar con la autoridad» que otros deberían "obedecer», «la disputa se refiere al establecimiento o reafirmación de las relaciones de superioridad o inferioridad, de dominación y sumisión, entre partidarios de diferentes creencias» (2001: 114).

11 Véase la relectura que Scott Lash hace de los términos «discursivo» y «figural» de Jean-Francois Lyotard para contraponer moderno y postmoderno. ¿Discurso o figura? El postmodernismo como «régimen de significación» (1990: 7). 
Según leemos en la obra El crimen perfecto de Baudrillard, la alta tecnología (high tech) también introduce radicales alteraciones en lo que entendamos por realidad, pero no se trata de que ésta se debilite, sino, todo lo contrario, de que se vigorice, convirtiéndose en más real que lo real, convirtiéndose, como el porta-botellas de Marcel Duchamp, en «hiperreal». ${ }^{12}$ La consecuencia que conlleva un mundo transformado, no ya en fábula, sino en hiperrealidad, es, asombrosamente, la misma que detecta Vattimo: la incertidumbre radical acerca de la verdad de los acontecimientos. Esa incertidumbre no la provoca el hecho de que los acontecimientos sean fácilmente maleables, ni tampoco susceptibles de consensuar, sino que viene determinada por la circunstancia de que la realización de lo real erradica del conocimiento del mundo - atención a la inversión a la que Baudrillard parece someter los presupuestos del pensamiento débil- el requisito previo de «fabularlo». Ello quiere decir que es el mundo no hiperrealizado, el mundo tal cual, el que resulta fabuloso o imaginario, pero, por eso mismo, insoportable, puesto que lo ilusorio es siempre misterioso e impenetrable. Para conjurar sus fantasmas, necesitamos «realizar lo real», darle fuerza, hacerle existir y significar a cualquier precio, y eliminar así su carácter secreto, arbitrario o accidental. Es esto lo que logra la alta tecnología. Para Baudrillard, el régimen de simulación en el que habitamos y al que todos contribuimos como actores de la performance (1996) (lo que aleja también su propuesta de la visión situacionista del mundo, que nos considera pasivos «espectadores» del «espectáculo» de la vida), ese régimen capitaneado por la tecnología reproductiva, se erigiría, pues, como una gigantesca empresa de "desilusión", literalmente, de "ejecución» (de ahí el "crimen perfecto») de la ilusión del mundo a favor de un mundo real, demasiado real. ${ }^{13}$ Por lo tanto, en la propuesta de Baudrillard, la realidad no se nos muestra precisamente en retroceso, sino que ha proliferado hasta dimensiones nunca vistas, "ha llegado a su colmo» (1996: 30-1), lo que ha terminado atentando contra la propia ilusión de realidad:

El crimen perfecto es el de una realización incondicional del mundo mediante la actualización de todos los datos, mediante la transformación de todos nuestros actos, de todos los acontecimientos en información pura; en suma: la solución final, la resolución anticipada del mundo por clonación de la realidad y la exterminación de lo real a manos de su doble (1996: 41).

12 Baudrillard, en un verdadero ejercicio de malabarismo intelectual, suele considerar los ready-made de Marcel Duchamp como antepasados de lo hiperreal, puesto que, como ellos, también éste es extraído de su vida para conferírsela en otro lugar, en un campo que denomina una hiperrealidad inefable, Acting-out paradójico o cortocircuito instantáneo. El portabotellas, «exinscrito» de su contexto, de su idea y de su función se haría así más real que lo real y más arte que el arte. De ahí nace también su formulación de una transestética que, a diferencia de la estética tradicional, se ocuparía de la banalidad, de la insignificancia y de la nulidad en que se han convertido las obras de arte; en definitiva, de la indiferencia recién conquistada del arte con respecto a la realidad (1996), capítulo «La escritura automática del mundo». Compárese su postura con la de Donald Kuspitt, que sentencia a raíz de ello el «fin del arte» (2006). Para el tema de la transestética, véase Baudrillard (2006).

13 Capítulo «La ilusión radical». Para Baudrillard (1996), el concepto clave de esta virtualidad es la Alta Definición, no sólo la de la imagen, sino también la del tiempo (el tiempo real), la de la música (la Alta Fidelidad), la del sexo (la pornografía), la del pensamiento (la IA), la del lenguaje (los lenguajes numéricos) o la del cuerpo (el código genético y el genoma). La Alta Definición, desplegada en todas estas metamorfosis, marca el paso, más allá de cualquier determinación natural, hacia una fórmula operativa — «definitiva» precisamente-, hacia un mundo en el que la sustancia referencial se hace cada vez más escasa. Ibídem, capítulo «La escritura automática del mundo». 
De ahí la reivindicación de devolver fuerza, no tanto a lo real, que ya la posee, sino a la ilusión. Como dice Baudrillard, es como si las cosas hubieran engullido su propio espejo y se hubieran convertido en transparentes, enteramente presentes, a plena luz, en una transcripción despiadada de sí mismas.

La actitud de Baudrillard hacia este mundo «desencantado» y «ultra-realista» es, a diferencia de la de Vattimo, negativa: si el mundo no hiperrealizado es insoportable debido a sus misterios, el hiperreal, en donde la realidad se ofrece en exceso - «obscenamente»-, nos deja mucho más ansiosos y desconcertados. Y ocurre así porque, ante la realización total de lo real, no existe negación ni superación posibles. Según el autor, carecemos incluso de un pensamiento que lo abarque debido a que ni siquiera luchamos contra las sombras o los fantasmas, sino que — ojo con esto- luchamos contra la mismísima «transparencia» (Baudrillard, 1996: 45).

¿Se corresponde esta otra visión de la postmodernidad y su tecnología con lo que plantea Blow-out? La reconstrucción audiovisual del asesinato, ¿desencanta el mundo?, ¿nos deja sin instrumentos para pensar?, ¿hace desaparecer lo real por llevarlo a su colmo? En mi opinión, no.

Para empezar, habría que decir que la «real-ización» tecnológica del asesinato que Jack «ejecuta» en su estudio no es percibida en ningún momento como algo negativo, sino, todo lo contrario, como la forma de desenmascarar una conspiración que ha traído consigo la muerte de varias personas. Evidentemente, el acontecimiento hiperrealizado tecnológicamente disipa las dudas y los misterios que en principio lo envuelven. En cierto modo lo "desencanta", pero ese desencantamiento es positivo porque permite que el protagonista tenga certeza de la verdad y encuentre sentido para lo ocurrido. Gracias al simulacro tecnológico del asesinato y pese a que finalmente éste queda impune, el espectador obtiene al menos el "consuelo» de saber cuál es la verdad, y el protagonista, aparte de ello, adquiere la recompensa de haber dirigido todos sus esfuerzos a descifrarlo. Lo que cuenta, al fin y al cabo, es la intención, que entraña un compromiso con la ciudadanía. En ningún momento, el realizador cuestiona la importancia de clarificar lo sucedido ni se muestra partidario de mantener intacto el encanto de un suceso real pero dramático. De la película se desprende más bien la idea de que la tecnología es un instrumento útil para la sociedad en tanto en cuanto posibilita el desvanecimiento de las dudas y las sospechas y en tanto actúa en consecuencia a favor de la libertad, el progreso y la justicia.

Esta es la razón por la que considero posible decir que la visión que de la postmodernidad y su tecnología tiene Baudrillard tampoco se acomoda a la película que nos ocupa. Intentar ajustarla nos colocaría en la tesitura de afirmar que el simulacro tecnológico del asesinato desencanta un acontecimiento dramático, lo que viene a ser lo mismo que decir que es mejor no aclararlo y dejarlo en su esencia ilusoria, dudosa, vaga o indeterminada. Analizar los presupuestos ideológicos de la película en lo que concierne a la técnica conduce, necesariamente, a negar esa afirmación, puesto que lo planteado por la película es precisamente que necesitamos dar sentido a las cosas, explicarlas o esclarecerlas, y que la técnica, más o menos sofisticada, nos ayuda en buena medida a lograrlo; más aún, lo que defiende el realizador de Blow-out es, frente a Baudrillard, que siempre hemos de luchar, no contra sino "por» la transparencia, porque, ahora sí, hacerlo nos hace libres. Por eso, tampoco desde este punto de vista podemos considerar la película de Brian de Palma como una cinta postmoderna.

El hecho de que esta otra teoría tampoco encaje con la película que comentamos tal vez tenga que ver con que, pese a lo que afirma Jameson, la tecnología que utiliza Jack 
en Blow-out todavía no ha alcanzado la sofisticación necesaria para lograr el verdadero hiperrealismo del que suele hablar Baudrillard. En comparación con la técnica digital desarrollada en los últimos años y de la que también se han apropiado los creadores de relatos futuristas de ciencia ficción, tipo Matrix, la tecnología que maneja en su estudio Jack, todavía, en ciertos aspectos, manual, se percibe, efectivamente, como rudimentaria, primitiva y desde luego obsoleta. Es muy discutible que en ella se aprecie, como insinúa Jameson, ni siquiera un pálido reflejo de lo sublime tecnológico, a menos que consideremos erróneamente que la metamorfosis postmoderna de la categoría estética romántica la haya conducido a significar algo parecido a lo grotesco.

Hay que destacar, para terminar con Blow out, que, pese a lo desigual de sus opiniones, tanto Vattimo como Baudrillard coinciden en sostener que los simulacros o la estetización de la realidad resquebrajan la tradicional barrera metafísica entre lo aparente y lo real. Que el mundo se convierte en fábula quiere decir, en la filosofía de Vattimo, que la oposición entre real y aparente ya no tiene sentido, pues una necesita de la otra. Pero si una se convierte en la otra, entonces esa distinción queda invalidada. Por eso el pensamiento débil es un pensamiento post-metafísico, que ha superado, o más propiamente dicho, ha ingresado en lo que Vattimo llama una Verwindung de la metafísica, a saber, una Überwindung impropia, una superación que no es tal en el sentido habitual de la palabra ni en el de la Aufhebung dialéctica, sino que señala que la metafísica, que ya no es aceptada, permanece en nosotros como los rastros de una enfermedad, como algo a lo que uno se remite o se recobra (1985: 152). En el caso de Baudrillard, lo hiperreal difumina también las distinciones entre los objetos y sus representaciones, puesto que los simulacros hiperrealistas no tienen como referente a la realidad, sino a sí mismos, toda vez que han perdido el contacto con los objetos significados y han erradicado toda distinción entre el mundo real y el de su representación. Como dice Baudrillard: «Vivimos en un mundo en el que la más elevada función del signo es hacer desaparecer la realidad, y enmascarar al mismo tiempo esa desaparición» (1996: 17). Por tanto, en la obra de Baudrillard, la simulación no se confunde con el fingimiento, ya que éste deja intacto, como en Vattimo, el «principio de realidad».

En el fondo de esta coincidencia, se halla una cuestión que todavía no hemos planteado pero que hemos de mencionar para articular desde ella la interpretación de la película de Michelangelo Antonioni. Me refiero a la base de todo el pensamiento postmoderno y que no es otra que la realización de aquello que Nietzsche profetizó para nuestro siglo como la llegada del nihilismo.

\section{BLOW-UP O EL ARTE DE «CREAR» LA REALIDAD}

La magistral película de Michelangelo Antonioni, basada en el relato de Julio Cortázar «Las babas del diablo», invita también a reflexionar sobre la relación entre apariencia y realidad, esta vez a través de la mediación que entre ellos introduce la cámara fotográfica. En efecto, como señala Frederic Jameson, tecnológicamente hablando, se ha producido un salto cualitativo más que considerable entre ésta y la otra película, pero podemos preguntarnos: el hecho de que aquí sólo contemos con una cámara fotográfica y no con un sofisticado despliegue tecnológico audiovisual, ¿impide que se pongan en cuestión las 
tradicionales relaciones dialécticas entre realidad y apariencia? Voy a tratar de demostrar que no.

\section{Desde el «ilusionismo» de la fotografía: alejarse es ver}

La escena que permite desarrollar lo arriba afirmado es la de la ampliación de las fotografías, aquella en la que se lleva a cabo eso que ya se conoce como «efecto Blow-up» (Bubois, 1994), a saber, que, conforme se van agrandando las imágenes capturadas por una cámara fotográfica, éstas revelan más y más información aunque pague el precio de la pérdida de nitidez.

$\mathrm{El}$ «efecto Blow-up» tiene un carácter paradójico: hace ver menos al tiempo que hace ver más; dicho en términos de Santos Zunzunegui, la creciente presencia del "grano» tiende a inclinar a la imagen del lado de la «representación», mientras que su disminución refuerza el «ilusionismo» realista (1992). Si nos quedamos con la segunda parte de la paradoja, el «ilusionismo» o el «hacer ver más» de la fotografía crecientemente ampliada, entonces debemos concluir que en la película tiene lugar un asesinato, pues eso es lo que «vemos» en su representación, y que la cámara fotográfica, que registra lo que parece un cadáver, representa fielmente la verdad, como la reconstrucción audiovisual que Jack lleva a cabo en Blow-out. Pareciera, según esto, que Antonioni, como Brian de Palma, nos estuviera desvelando la realidad a través de la apariencia, y que la ampliación de las fotografías no fuera otra cosa que una continua «explosión» (blow up) de referentes. Ello explicaría el drama de extraviar, al final de la película, la secuencia de las fotografías, únicas pruebas de lo que pareciera haber ocurrido en el parque. Para esta interpretación de corte realista, la imagen fotográfica, de la que no dudamos, remitiría necesariamente a un referente que la trasciende, indicaría que existe una continuidad de la imagen con lo real, y confiaría, en última instancia, en el poder de las apariencias para desvelar lo verdadero, una visión de la película que suscribiría los presupuestos y escisiones de la metafísica moderna.

Seguramente esta exégesis ha sido preponderante porque tiene que ver con las consideraciones teóricas que tradicionalmente se han ofrecido acerca de la naturaleza de la imagen fotográfica, a la que, desde su invención, se le atribuyó una credibilidad indubitable sostenida sobre su evidente resultado mimético. En virtud de su modo de producción, se pensó que esta nueva forma de representar no podía mentir, que, todo lo contrario, atestiguaba incontestablemente la existencia de lo que ella misma daba a ver (Dubois, 1994). ${ }^{14}$

Como ejemplo de una teoría referencialista o realista — concretamente indexal- de la fotografía, que podría amparar las interpretaciones de la película de Antonioni que defienden que en ella tiene lugar un asesinato, podemos citar a Roland Barthes, quien dedicó a la fotografía un bello ensayo titulado La chambre claire. Note sur la photogra-

14 Esto tiene que ver también con el hecho de que en casi todas las definiciones de la imagen estén implícitas las ideas platónicas de representación y de reflejo especular. La filosofía clásica, de la que esta caracterización de la fotografía es deudora, entiende la representación como una «función del lenguaje en general», como lo que tiene como función el estar en lugar de otra cosa a través de una representación, lo que «ofrece de nuevo pero transformado en signo» lo que ya existe en la vida o en la imaginación. Véase también Santos Zunzunegui (1992), los capítulos «Etimologías y definiciones» y «La representación como función del lenguaje en general». 
phie. Barthes deseaba distanciarse de todas aquellas teorías, provenientes de la sociología y de la semiótica y que habían ahormado hasta entonces su pasado intelectual, que tendían a interpretar la fotografía desde su relatividad semántica, desde su carácter de «fabricación» o constructo, ${ }^{15}$ desde lo que Dubois ha denominado teoría transformativa de la fotografía.

Renunciando, pues, a su pasado semiótico, Barthes calificaba a la fotografía como un mensaje sin código, lo que le conducía a definir su noema como un "esto-ha-sido", como la «emanación del referente» (1990: 142), o la «metonimia del punctum»: «Lo que intencionalizo en una foto (no hablemos todavía del cine) no es ni el Arte, ni la Comunicación; es el Referente, que es el orden fundador de la Fotografía» (136). En el noema barthesiano, se aprecia una doble posición de realidad y de pasado según la cual cada acto fotográfico constituiría una «microexperiencia de la muerte», ya que, al verme o ver a otros en el papel, vivencio, dice Barthes, un sentimiento subjetivo (con validez intersubjetiva) del devenir como objeto cuya radicalización es el spectrum. Éste alude al blanco, al referente, a «una especie de pequeño simulacro, de eidôlon, emitido por el objetivo» (38), y Barthes lo llama spectrum porque la palabra «mantiene a través de su raíz una relación con «espectáculo〉 y le añade ese algo terrible que hay en toda fotografía: el retorno de lo muerto» (39). En el noema fotográfico barthesiano lo importante sigue siendo el referente, que se encuentra en el pasado y que, como afirma insistentemente en la obra, acompaña siempre -ineludiblemente- a la fotografía: «Nunca puedo negar en la Fotografía que la cosa haya estado allì (136). Este referente fotográfico aludiría, no a la cosa «facultativamente» real, sino a la cosa «necesariamente» real que ha sido colocada ante el objetivo de la cámara y sin la cual no puede haber fotografía. Desde la perspectiva barthesiana, quien contempla una fotografía debe — no le queda más remedio- confiar en lo que ve, puesto que entre la imagen y su referente existe una contigüidad instantánea y necesaria que impide cualquier tipo de vacilación. Según este autor, la fotografía no dice «lo que ya no es», sino tan sólo y sin duda alguna «lo que ha sido». Ante una fotografía, la conciencia no toma por tanto la única vía nostálgica del recuerdo, sino, sobre todo, la de la certidumbre, puesto que la esencia de la imagen fotográfica consiste en ratificar lo que ella misma representa.

Si esta teoría es cierta, entonces, lo que Thomas ve en la secuencia fotográfica ampliada es necesariamente real, incuestionable y cierto, y ha de llegar, por tanto, a la conclusión de que en el parque londinense se ha producido un asesinato. Pero ¿es realmente así?

Habría que tener en cuenta, en primer lugar, lo borrosa que resulta la última ampliación fotográfica, aquella en la que, según nos hace ver el protagonista, parece percibirse un cadáver, pero en la que otros personajes de la película, como Patricia, no ven más

15 Uno de sus blancos es Raúl Becerro, en concreto su libro Ensayos sobre la fotografía (1978). Para ilustrar mínimamente su postura ante este debate, transcribimos la siguiente declaración: «Tal debate es vano: nada puede impedir que la Fotografía sea analógica; pero al mismo tiempo el noema de la fotografía no reside en modo alguno en la analogía (rasgo que comparte con toda suerte de representaciones). Los realistas, entre los que me cuento y me contaba ya cuando afirmaba que la Fotografía era una imagen sin código -incluso si, como es evidente, hay códigos que modifican su lectura-, no toman en absoluto la fotografía como una "copia» de lo real, sino como una emanación de lo real en el pasado: una magia, no un arte. Interrogarse sobre si la fotografía es analógica o codificada no es una vía adecuada para el análisis. Lo importante es que la foto posea una fuerza constativa, y que lo constativo de la Fotografía ataña no al objeto, sino al tiempo. Desde un punto de vista fenomenológico, en la Fotografía el poder de autentificación prima sobre el poder de representación» (Barthes, 1990: 153-5). 
que una especie de cuadro abstracto; en segundo lugar, pero no por ello menos importante, habría que considerar también el hecho de que, a diferencia de Brian de Palma, Antonioni, que parece blandir una bandera a favor de la superación del neorrealismo italiano, nos escamotea de forma premeditada cualquier tipo de información conclusiva acerca del supuesto crimen, de lo que realmente ocurrió, de la realidad en sentido fuerte. La duda acerca del dramático acontecimiento es continua a lo largo de la cinta, pues el cadáver, así como la mujer en apariencia cómplice del asesinato, aparecen y desaparecen sin lógica ni explicación. En realidad, nada sabemos de lo acontecido en el parque, ni siquiera gracias a la fotografía, que, conforme se amplía, resulta — debido a las particularidades del «efecto Blow-up»- más y más borrosa. Teniendo en cuenta estos detalles, ¿no es demasiado osado afirmar tajantemente que en Blow-up tiene lugar un asesinato?, ¿no podríamos incluso pensar que la última fotografía, por mucho que siga siendo una fotografía, desvela no tanto lo que ya no es, sino, tal vez, "lo que nunca ha sido»?, ¿no deberíamos tener en cuenta la falta de información que tenemos del supuesto crimen, que, llegados al final de la película, sigue sin esclarecerse?, ¿no hay demasiadas ambigüedades en la película como para pensar que cualquier afirmación en torno al asesinato resulta fácilmente rebatible?

Acogerse a las teorías tradicionales que consideran a la fotografía como testigo indubitable de lo real dirige la lectura y la interpretación de la película de forma errónea y provee a los exegetas de Antonioni de una coartada para desestimar y dejar sin explicación el trasfondo nihilista que la sustenta y que tanto la caracteriza estética e ideológicamente. La película de Antonioni no sería sin duda la misma sin esa atmósfera enrarecida, sin esa tonalidad enigmática y desconcertante que hace sentir perdido al protagonista y que le obliga a mirar a su alrededor con ojos de incomprensión. La película de Antonioni ni siquiera es un thriller, como la de Brian De Palma; el supuesto asesinato de no sabemos quién, para qué, ni por qué no es en realidad más que el pretexto para introducir en ella una reflexión profunda y radical que quiere poner entre interrogantes la naturaleza misma de lo real. Por eso, aducir que en ella acontece un asesinato y que la fotografía simplemente nos lo hace ver, es una lectura pobre y reduccionista, que deja sin explicación detalles tan importantes como la aparición continua de los mimos, por poner un solo ejemplo, que terminan pareciendo argumentalmente gratuitos. Desde mi punto de vista, para entenderla correctamente hay que empezar por cuestionar, a contracorriente de lo que dice Barthes, la creencia en la referencialidad misma de la fotografía, lo que, lejos de dejarnos sin asidero, nos permitirá interpretarla desde una perspectiva integradora que, ahora sí, puede explicar muchos de los elementos en apariencia fútiles de esta enigmática película.

\section{Desde la «representación» granulosa: acercarse es «crear»}

Los autores que se han enfrentado a Blow-up con una actitud más escéptica, inclinándose no tanto por el «ilusionismo» de la distancia fotográfica cuanto por la «representación» que exige su proximidad, han detectado que los espectadores de la película poseemos dudas más que razonables acerca de lo que la imagen fotográfica ampliada da a ver. Ricardo Paredes Quintana, por ejemplo, atribuye a la fotografía, relativizando así el noema barthesiano, cierto carácter fantástico o fantasmagórico, que se revelaría, en el caso que nos ocupa, justamente en el juego de revelado de la imagen crecientemente 
ampliada. La mítica escena de Antonioni le da pie a proponer que quizás debiéramos sustituir la certeza icónica (¡esto ha sido!) por una aporía óptica (¿esto ha sido?) (Paredes Quintana, 1999), concediendo cierto lugar a la vacilación. Philippe Dubois, por su parte, ha explicado que, puesto que la huella fotográfica es discontinua, cuanto más visible es el grano de halogenuro, que compone su unidad mínima, más imprecisa y peor definida es la imagen, que se instala así en una progresiva "confusión» figurativa que roza el puntillismo. Y el puntillismo, naturalmente, es global e indiferente, desmorona la continuidad de las figuras y diluye el analogismo icónico. Eso quiere decir que para «leer» la imagen hay que estar colocado a distancia suficiente, la suficiente como para que los granos se tornen en provecho de la figuración. No hacerlo trae consigo que dudemos, y que, como ocurre en la última ampliación de Blow-up, «todo se pierda y se diluya», tanto que «se puede comparar con un cuadro abstracto mientras que quizás es la foto de un cadáver» (Dubois, 1994: 99).

A estas otras interpretaciones más desconfiadas de Blow-up contribuyen desde luego muchos detalles de la película que los intérpretes realistas han dejado sin considerar: para empezar el hecho de que el cadáver «real», no el fotografiado, aparezca y desparezca de la trama sin más explicación. Es importante resaltar de nuevo que, a diferencia de Brian de Palma, Antonioni nos escamotea cualquier tipo de información acerca del supuesto asesinato, y que lo hace, además, adrede. Ni siquiera podemos acudir a la actitud del personaje interpretado por Vanesa Redgrave, tan interesado en recuperar el carrete, pues, al final de la película, de la cual hace tiempo ella también ha desaparecido sin explicación, ${ }^{16}$ seguimos sin disipar las dudas acerca de sus verdaderos intereses: ¿está buscando ocultar un asesinato o, simplemente, como pensamos todos al principio, un romance prohibido o escandaloso? Nada se nos informa al respecto. Antonioni nos muestra además, y esto es muy significativo, que el único que $\dot{i}$ «ve? el cadáver en el parque es Thomas, nadie más, y que lo hace, además, durante la noche y después de un sintomático deambular psicodélico por locales londinenses. No es casualidad que en esa «bajada a los infiernos» los protagonistas sean los narcóticos alucinatorios y una música rock altamente embriagadora, que incita a los espectadores del concierto, incluido Thomas, a disputarse los pedazos de una guitarra eléctrica, percibida, básicamente, como un fetiche irreemplazable. De hecho, cuando Thomas se marcha del local, lo primero que hace es arrojar al suelo, como si fuese basura, el trozo de la guitarra por el que minutos antes ha luchado encarecidamente, tal vez porque el escenario es ahora el de una anodina calle y no el febril de los espectáculos musicales. Salir del contexto artístico es, entonces, como atravesar esa liviana frontera que separa lo «significativo» de lo «insignificante», es decir, lo que tiene sentido de lo que carece de él.

Además, ahondando en la incertidumbre en la que nos sumerge desde el inicio la película, hay que tener en cuenta que la serie de las fotografías, como la reconstrucción audiovisual de Jack en Blow-out, desaparece misteriosamente del estudio del fotógrafo, pero, a diferencia de lo que ocurre en la película de De Palma, los espectadores desconocemos quién lo ha robado y por qué. De ellas sólo queda la última ampliación, aquella en

16 Nuria Bou ha analizado el tratamiento cinematográfico de la mujer constatando cómo, durante la primera parte del film, Thomas la observa siempre en plano general, mientras que hacia el final de la película aparece como fantasmagórica aparición: mientras Thomas corre buscando a un amigo, cree verla por la calle, la sigue, pero la pierde en la ciudad y desconocemos de hecho si es o no la mujer buscada (2002), véase el capítulo «La obra de Michelangelo Antonioni, La realidad, indiferente a la mirada: la obra de Antonioni desde Blow-up (1966) a Identificazione di una donna (1982)». 
la que «parece» divisarse un cadáver, pero en la que los granos de halogenuro son ya tan enormes que, con toda razón, desconfiamos de las apariencias. Esta última ampliación recuerda de hecho a ese juego infantil que consiste en "ver formas» en las nubes, un juego, de reminiscencias gestálticas, en el que la protagonista es ante todo la «imaginación», y que, como actividad dispendiosa e irresponsable, permite a cada cual decir lo que quiera. Y sin embargo se trata de una fotografía, de la «reproducción tecnológica de la realidad más fiel», de un tipo de imagen que atestigua sin sospechas lo que ha acontecido (esto-hasido). ¿No podría ser que la supuesta imagen del cadáver sea también, como el juego de las nubes, fruto de la intervención imaginativa de Thomas? ¿No podría simbolizar, como ocurre con el trozo, primero significante y después anodino, de la guitarra eléctrica, la capacidad que posee el arte de conferir sentido e incluso de «vivificar» la realidad?

La clave de ello radica, creo posible decir, no tanto en la técnica fotográfica, que aquí no funciona sino como pretexto, cuanto en el poder del arte, que en la película de Antonioni es simbolizado tanto por el fotógrafo como, sobre todo, por el grupo de mimos que desde el comienzo de la cinta acompañan en segundo plano al protagonista, y que la culminan con un enigmático partido de tenis recreado de forma mimética. La aparición de los mimos en el film ha generado diferentes interpretaciones que Peter Brunette ha sintetizado en un libro sobre el cine de Antonioni: hay quien piensa que los cómicos simbolizan el arte, que, como juego, es siempre ilusorio; otros, entre los que se incluye Brunette, piensan que el artista debe aprender que «la realidad se construye inconscientemente y se construye socialmente» (1998: 117). ${ }^{17} \mathrm{Y}$ otros, entre los que me incluyo, opinan, recogiendo los ecos calderonianos, que lo que es ilusorio no es tanto el arte como la vida. Argumentaré, para finalizar el artículo, por qué esta última interpretación puede ser considerada un rasgo de la postmodernidad, y por qué, por extensión, me atrevo a etiquetar de esa manera la película de Antonioni.

Pensemos que la cinta termina cuando la invisible pelota con la que los mimos «fingen jugar» cae fuera de la pista, y Thomas, que está contemplándolos, «juega también a fingir» yendo a buscarla y devolviéndosela. La ficción, entonces, deja de ser lo que era, puesto que, milagrosamente, cuando la pelota «inexistente» es devuelta a la pista, comienza a sonar "como una pelota de verdad». La magia del arte, vaticinada por Nietzsche desde la exaltación del espíritu dionisíaco en El origen de la tragedia, se ha puesto en marcha mostrándonos que es el artista, como se presagia en el concierto de rock a través de la guitarra destrozada, quien da vida a las cosas, quien las hace existir, quien hace y deshace, quien da sentido a lo que tal vez no lo tenga. Si tenemos en cuenta que Nietzsche constituye para los postmodernos el maestro fundador y que uno de los temas del debate que han inaugurado gira en torno a la realidad o irrealidad (Lyon, 2000), acudir a Nietzsche puede que sea la manera más idónea de enhebrar una lectura postmoderna de la película Blow-up.

Recordemos que Nietzsche considera, desde sus primeros escritos, que el hombre dionisíaco y artista (Thomas), en tanto imitador de la poiesis original del fondo primordial en la que se debate la lucha entre lo apolíneo y lo dionisíaco, no es preso de las figuras estables, como el apolíneo, sino que, trascendiendo la mirada ilustrada de raigambre socrática, supera la escisión entre apariencia y realidad ahormando las cosas en un pro-

17 Para las diversas interpretaciones que ha obtenido la escena final de Blow-up, véase Seymor Chatman y Paul Duncan (ed.), 2004. 
ceso ininterrumpidamente creador. ${ }^{18}$ De alguna manera, en la metafísica nietzscheana del artista que se expone en El origen de la tragedia y que posteriormente dará lugar a una teoría del genio, se prefigura la imagen del superhombre (Fink, 1966). ${ }^{19}$ Cuando a ello se le una la diatriba que Nietzsche declara, a partir de Humano, demasiado humano, a las escisiones metafísicas, entre ellas la de apariencia y realidad, el camino estará sembrado para desembocar en la promulgación nihilista del superhombre como nuevo creador de valores. El discurso de Zaratustra titulado «De las transformaciones», en el que la esencia del ser humano se metamorfosea desde la autoalienación a la libertad creadora y lúdica ejemplificada por la imagen del niño, es un buen ejemplo de ello. Thomas puede considerarse el trasunto de este niño nietzscheano en tanto en cuanto ejerciendo, a la manera de juego, la libertad individual, crea, convirtiendo el juego, como dice Fink, en «la estimación axiológica del hombre» (85). Y no lo hace sólo ante el juego de tenis. Pensemos que el supuesto cadáver cobra existencia siempre que Thomas está delante de él o de su representación: es Thomas, y sólo Thomas, el que nos hace ver que en la última ampliación de sus fotografías parece divisarse un cadáver (es posible, si él no lo viera, ninguno de nosotros lo haría, como le ocurre a su amiga Patricia); es Thomas, y sólo Thomas, el que, después de su bajada al underground londinense, ve el cadáver en el parque — curiosamente nadie más está presente para corroborarlo—; y es Thomas, y sólo Thomas, quien puede hacer que un partido de tenis fingido se torne real. Tal vez haya que tener más en cuenta de lo que hasta ahora se ha hecho el carácter individualista del protagonista, del que depende todo lo que ocurre, incluida la falta de delimitación que existe entre lo aparente y lo real, que deja de ser, como antaño, una cuestión objetiva y empíricamente demostrable más allá de la copia o de la propia subjetividad.

Ese crear individualista, del que es encarnación el fotógrafo de Antonioni, se torna casi necesario en la filosofía nietzscheana si tenemos en cuenta que el anuncio de la muerte de Dios tiene que ver con el deseo de erradicar el sustancialismo tradicional, lo que en la película que nos ocupa se traduce en la falta de consistencia que adquiere la realidad y su imagen, que se hacen y deshacen al antojo del protagonista. Desde la etapa crítica, Nietzsche, convencido de que la metafísica tradicional es nihilista, había sustituido el concepto de ser por el de voluntad de poder para hacernos ver, como también nos hace ver Antonioni, que el ser no es más que interpretación, que vivir es evaluar, poner significados, crear valores. Desde Nietzsche sabemos, y es eso lo que ha trascendido entre los postmodernos, que el problema que nos atañe no es ya saber cuál es la verdad y cuál su representación, puesto que buscar lo verdadero implica postular un criterio que tendría que suponer, a su vez, la posibilidad de conocer el ser, lo cual es imposible (Sánchez Meca, 1989). Lo que queda entonces — y esta es la enseñanza de Nietzsche- es la libertad lúdica de cada cual, que ha de «crear» — ya no hay sitio para las copias—, desde su individualidad y sabiéndose instalado en el nihilismo. La verdad postmoderna es por eso

18 Como dice Eugen Fink, al final de El origen de la tragedia, la diferencia entre voluntad y representación o fenómeno ya no es considerada como una demarcación que separa dos ámbitos, sino que se la interpreta como un movimiento, como un proceso creador: así como el fondo primordial crea el mundo jugando, así también el artista que lo imita en su proceso creador, repite la poiesis de la vida universal (1966). Gianni Vattimo, por su parte, dice que: «Junto a la idea de que la sabiduría dionisiaca es algo ante lo que el griego tiende a huir, por el temor de ver en virtud de ella los caracteres caóticos y abismales de la existencia, corre a lo largo de toda la obra, y a menudo más bien parece predominar la otra idea de que lo dionisíaco es, por su misma naturaleza, por la sobreabundancia y la multiformidad que encierra en sí mismo, potencia plástica, formadora de apariencias y de ilusiones siempre nuevas, como el impulso metaforizante de que habla el escrito sobre la verdad» (2003: 47).

19 Véase también Sánchez Meca (1989: 55). 
retórica o estética, como ha señalado Vattimo, ${ }^{20}$ y en tanto depende de la voluntad de poder, también es necesariamente shwingend, oscilante (1998: 158), similar a la fluctuación que exterioriza la fotografía ampliada del cadáver, que ya no es espejo de nada, y similar también al movimiento imparable de las nubes en las que se hacen y deshacen las figuras que creemos y queremos ver.

Creo posible decir que la película Blow-up invita a reflexionar sobre lo poco real que es la realidad, aunque también, en la estela platónica, sobre lo poco representativa que es la representación. Antonioni parece mostrar a lo largo de la película un tono pesimista ante la incertidumbre nihilista sobre la que nos movemos. Después de su descubrimiento, Thomas se muestra desconcertado, perdido y desconfiado. Pero, pese a que la realidad se ha desvanecido y no queda ningún suelo al que aferrarnos - una experiencia y un sentimiento, ahora sí, lindantes con lo sublime-, el final termina transmitiendo un tono esperanzador. Tal vez no conozcamos la verdad de lo acontecido y nos sintamos, por eso, inseguros y desorientados, pero, a cambio, puede que aprendamos una gran lección genuinamente nietzscheana: que no hay ninguna verdad, y que, por tanto, somos o hemos de ser como el hombre artista, aquel que, conociendo lo falsas que son las cosas estables, incluidas sus representaciones, se mueve libremente creando metáforas sin olvidar que lo son.

Ello podría explicar la sonrisa que Thomas dirige a los mimos en el último plano de la película, una sonrisa que se complace de saber que quizás el nihilismo sea, como quiere Vattimo, nuestra única oportunidad.

\section{REFERENCIAS}

Barman, Zigmunt. (2001). La postmodernidad y sus descontentos. Madrid: Akal. Barthes, Roland. (1990). La cámara lúcida. Nota sobre la fotografía. Barcelona: Paidós Comunicación.

Baudrillard, Jean. (1996). El crimen perfecto. Barcelona: Anagrama.

- (2006). El complot del arte. Madrid: Amorrortu Ediciones.

Becerro, Raúl. (1978). Ensayos sobre la fotografía. México: Arte y Libros.

Bou, Nuria. (2002). Plano/contraplano. De la mirada clásica al universo de Michelangelo Anonioni. Madrid: Biblioteca Nueva.

Brunette, Peter (ed.). (1998). The film of Michelangelo Antonioni. The films of Michelangelo Antonioni. Nueva York: Cambridge University Presseditorial.

Cantero, Marcial. (2000). Brian de Palma. Madrid: Cátedra.

Chatman, Seymor y Paul Duncan (ed.). (2004). Michelangelo Antonioni. Madrid: Taschen.

Colmena, Enrique. (1987). Brian de Palma. Madrid: Ediciones JC.

Dubois, Philippe. (1994). El acto fotográfico. De la representación a la recepción. Barcelona: Paidós Comunicación.

Fink, Eugen. (1966). La filosofía de Nietzsche. Madrid: Alianza.

20 «En términos mucho más generales y con un conjunto de significaciones que apenas se comienza a explorar, se puede decir que la experiencia postmoderna (y para decirlo en términos heideggerianos, postmetafísica) de la verdad es, probablemente una experiencia estética y retórica» (Vattimo, 1998: 20). 
Jameson, Frederic. (1996). La lógica cultural del capitalismo tardío. Teorías de la postmodernidad. Madrid: Trotta.

Kuspitt, Donald. (2006). El fin del arte. Madrid: Akal.

Lash, Scott. (1990). Sociología del postmodernismo. Buenos Aires: Amorrortu Editores.

Lyon, David. (2000). Postmodernidad. Madrid: Alianza.

Lyotard, Jean-François. (1994). La condición postmoderna. Madrid: Cátedra.

Lipovetsky, Gilles. (1990). El imperio de lo efimero. La moda y su destino en las sociedades democráticas. Barcelona: Anagrama.

Paredes Quintana, Ricardo. (1999). Sueños en Polaroid: Fotografía, Epistemología y Ciencias Sociales. Cinta de Moebio, n 5 , abril. Facultad de Ciencias Sociales, Universidad de Chile. Obtenido desde <http://redalyc.uaemex.mx/redalyc/src/inicio/artPdfRed.jsp?iCve $=10100511>$.

Sánchez Meca, Diego. (1989). En torno al superhombre. Nietzsche y la crisis de la modernidad. Barcelona: Anthropos, Universidad de Murcia, Secretariado de Publicaciones.

Vattimo, Gianni. (1994): Postmodernidad: ¿una sociedad transparente? En Gianni Vattimo, y otros autores. En torno a la postmodernidad. Barcelona: Anthropos.

-. (1998). El fin de la modernidad. Nibilismo y hermenéutica en la cultura postmoderna. Barcelona: Gedisa.

-. (2003). El sujeto y la máscara. Nietzsche y el problema de la liberación. Barcelona: Península.

Zunzunegui, Santos. (1992). Pensar la imagen. Madrid: Cátedra, Universidad del País Vasco, Signo e imagen.

\section{Filmografía}

Antonioni, Michelangelo (dir.). (1966). Blow-up. Guión: Ted Elliott y Terry Rossio. Música: Herbie Hancock. Fotografía: Carlo di Palma. UK/Italia.

De Palma, Brian (dir.). (1981). Blow-out. Guión: Brian de Palma. Música: George Litto. Estados Unidos. 